NBER WORKING PAPER SERIES

\title{
GLOBALIZATION, MACROECONOMIC PERFORMANCE, AND MONETARY POLICY
}

Frederic S. Mishkin

Working Paper 13948

http://www.nber.org/papers/w13948

\author{
NATIONAL BUREAU OF ECONOMIC RESEARCH \\ 1050 Massachusetts Avenue \\ Cambridge, MA 02138 \\ April 2008
}

Based on a speech given at the Conference on Domestic Prices in an Integrated World Economy, Board of Governors of the Federal Reserve System, Washington, D.C., September 27, 2007. The views expressed here are my own and are not necessarily those of the Board of Governors of the Federal Reserve System, or the National Bureau of Economic Research. I want to thank Steven Kamin and Jaime Marquez for their helpful comments and assistance on this speech.

NBER working papers are circulated for discussion and comment purposes. They have not been peerreviewed or been subject to the review by the NBER Board of Directors that accompanies official NBER publications.

(C) 2008 by Frederic S. Mishkin. All rights reserved. Short sections of text, not to exceed two paragraphs, may be quoted without explicit permission provided that full credit, including $\odot$ notice, is given to the source. 
Globalization, Macroeconomic Performance, and Monetary Policy

Frederic S. Mishkin

NBER Working Paper No. 13948

April 2008

JEL No. E52,F41

\begin{abstract}
$\underline{\text { ABSTRACT }}$
The paper argues that many of the exaggerated claims that globalization has been an important factor in lowering inflation in recent years just do not hold up. Globalization does, however, have the potential to be stabilizing for individual economies and has been a key factor in promoting economic growth. The paper then examines four questions about the impact of globalization on the monetary transmission mechanism and arrives at the following answers: (1) Has globalization led to a decline in the sensitivity of inflation to domestic output gaps and thus to domestic monetary policy? No. (2) Are foreign output gaps playing a more prominent role in the domestic inflation process, so that domestic monetary policy has more difficulty stabilizing inflation? No. (3) Can domestic monetary policy still control domestic interest rates and so stabilize both inflation and output? Yes. (4) Are there other ways, besides possible influences on inflation and interest rates, in which globalization may have affected the transmission mechanism of monetary policy? Yes.
\end{abstract}

Frederic S. Mishkin

Board of Governors of the Federal Reserve System

20th Street and Constitution Ave., N.W.

Room B-2052

Stop 47

Washington, DC 20551

and NBER

fsm3@columbia.edu 
In recent years, globalization has become one of the hottest topics, not only for the general public but also for central bankers. Some commentators have gone so far as to claim that greater openness of economies to flows of goods, services, capital, and businesses from other nations invalidate traditional economic models of inflation, which take little account of globalization.

In the long run, monetary policy strives to achieve price stability, which contributes to maximum sustainable employment and economic growth. In the shorter run, the Federal Reserve aims to achieve our dual mandate of not only stabilizing prices but also reducing the volatility of output and employment around their maximum sustainable levels. Globalization affects the ability of monetary policy makers to stabilize prices and output in two ways: (1) through its effects on the behavior of inflation and output and (2) through its effects on the ways in which monetary policy influences inflation and output--that is, on the monetary transmission mechanism.

I will look at each in turn and will then use the analysis to address another important issue for monetary policy makers: Has globalization been a key driver of improvements in inflation performance and the decline in inflation that we have been seeing throughout the world?

\section{Globalization and Inflation}

We should never forget Milton Friedman’s adage that “inflation is always and everywhere a monetary phenomenon.” In the long run, as long as a central bank has an independent monetary policy--that is, it is not locked into a fixed-exchange-rate regime in which its hands are tied--the rate of inflation is determined by monetary policy. Globalization, 
however, can have an effect on the incentives for central banks to control inflation and, more directly, on inflation developments in the short and medium runs.

Kenneth Rogoff (2003) argues that globalization has led to greater price flexibility, which has reduced the ability of central banks to use inflation surprises to boost output. In other words, the Phillips curve will steepen, making more stark the short-run tradeoff between unemployment and inflation. As a result, central banks will be less tempted to try to exploit the short-run tradeoff between inflation and unemployment, as in the Barro-Gordon (1983) model, and so will be less likely to pursue overly expansionary monetary policy that leads to higher inflation. A major problem with Rogoff's argument is that instead of steepening with the growth of globalization in recent years, the Phillips curve has become flatter, not only in the United States but also in many other countries throughout the world (Borio and Filardo, 2007; International Monetary Fund, 2006; Ihrig and others, 2007; Pain, Koske, and Sollie, 2006). Therefore, even though Rogoff's argument is reasonable from a theoretical viewpoint, it is hard to make the case that it is important in the current economic environment.

Globalization, because it makes markets more competitive, also has the potential to spur productivity growth. Higher productivity growth can lead to a reduction in inflation because it directly lowers prices if monetary policy does not become more expansionary. In addition, such growth makes it easier for the monetary authorities to allow inflation to fall because output growth will continue to be rapid when inflation is declining. This may have been the situation in the United States in the late 1990s, when productivity growth surged and inflation declined. The rise in productivity growth during this period in the United States, however, did not seem to spill over to other industrial countries, a result that cast doubt on whether globalization has indeed accelerated the transmission of productivity growth across national borders. 
Because globalization increases competition, it can also reduce markups (price over costs), and this reduction may lead to lower relative prices, as is argued by Chen, Imbs, and Scott (2007). However, lower markups and price levels should have only transitory effects on inflation. Furthermore, the prediction of lower markups from globalization seems to conflict with the high corporate profit rates that we are currently observing around the world.

These effects from the greater price flexibility and increased competition in domestic markets that have arisen from globalization, while theoretically plausible, are often at variance with salient features of the world economy, and so they do not explain why inflation has declined in recent years. However, another very dramatic feature of globalization is that it has brought more than a billion new workers into the global economic system from China and India. Some observers claim that through its sales of low-cost goods, developing Asia--and especially China--has been "exporting deflation" and will continue to do so until wages in these countries rise. Although this effect, too, is plausible, research suggests that its importance should not be exaggerated.

If China were truly exporting deflation, the effect should be evident primarily in the behavior of import prices. Research at the Federal Reserve Board by Kamin, Marazzi, and Schindler (2006) estimates that purchases of manufactures from China have lowered U.S. import price inflation roughly 1 percentage point annually over the past decade, a decline that has led to a short-run lowering of consumer price inflation of about one-tenth of 1 percentage point and a somewhat larger effect over the longer term. Research at the Organisation for Economic Cooperation and Development (OECD) by Pain, Koske, and Sollie (2006) arrives at a similar estimate of the effect of trade in manufactures with developing countries on U.S. inflation: negative 0.2 to negative 0.3 percentage point. 
At the same time, the additional demand for primary commodities by developing Asia, especially China and India, is putting upward pressure on global prices of these goods. During 2004-06, the region accounted for about 40 percent of the global growth in demand for oil and more than 70 percent of the growth in demand for copper and zinc. The global commodities boom, which has been stimulated by the emergence of the Chinese and Indian economies on the international scene, has been an important offset to the deflationary effects from their low-priced goods and services.

Analysis by the Board's staff, which weights the negative effect on U.S. inflation from cheaper manufactures against the positive effect from higher commodity prices, finds that the net effect in recent years could go either way but in any case is probably quite small. Looking back before the recent boom in commodities prices, the staff's best estimate is that China's and India's entrance on the global trading scene has had a small negative effect on inflation. Research at the OECD (Pain, Koske, and Sollie, 2006) reaches similar conclusions, finding a net effect of 0 to negative $1 / 4$ percentage point for the United States, the euro area, and the OECD economies in aggregate.

Laurence Ball (2006) makes an important point that cheaper imports from places like China lower relative prices for imported goods but ultimately do not affect inflation, which is the change in overall prices. Following the argument made by Milton Friedman (Friedman, 1974), Ball points out that for every decline in the relative price of one good or service in a price index like the consumer price index (CPI), there is by definition a rise in the relative price of some other good or service. Any pattern of relative-price changes is compatible with a particular level of the inflation rate. What determines the overall inflation rate is not relative prices for one category of goods and services but rather the balance between overall demand and supply in the 
economy, which ultimately is influenced by monetary policy. Ball therefore takes the view that cheap imports from China and other low-wage economies should not affect inflation.

I would not go as far as Ball does for the reason that changes in relative prices in an important category of goods and services could affect inflation for a considerable period of time. Nevertheless, his argument, as well as the research cited earlier, indicates that many of the exaggerated claims that globalization has been an important factor in lowering inflation in recent years just do not hold up.

\section{Globalization and Output}

The increasing integration of the global economy can have several effects on output. It is thus of concern to monetary policy makers because it can affect both output volatility and our forecasts of the economy.

Globalization may stabilize output by enabling producers to service a diversified global market rather than just the domestic market. Research at the Federal Reserve Board (Ihrig and others, 2007) documents that net exports tend to be negatively correlated with domestic demand and thus stabilize output; other research (Guerrieri, Gust, and López-Salido, 2007) finds that shocks to domestic demand move output less in more open economies. In the opposite direction, greater trade integration--including greater trade in services (Markusen, 2007)--could raise output volatility as countries become more vulnerable to foreign shocks. There is indeed some evidence that this situation has occurred in Mexico (Bergin, Feenstra, and Hanson, 2007).

As with the effects of greater trade integration on the volatility of output, the effects of financial globalization can go both ways. Increasing global diversification lowers the likelihood that financial shocks will be concentrated in individual economies and thus lead to economic 
downturns. Furthermore, as I have emphasized in my writings (Mishkin, 2006a), financial globalization can help promote institutional reforms that can make the financial system more stable, thereby contributing to more output stability. However, as I have also emphasized in my work (Mishkin, 2006a, chap. 4), financial globalization makes it easier for capital inflows to fuel excessive risk-taking on the part of financial institutions and allows financial shocks to be transmitted more readily across borders.

On balance, my sense is that economic globalization has the potential to be stabilizing for individual economies as both real and financial shocks are spread more evenly across larger numbers of economic agents. One might even speculate that globalization has contributed to the so-called Great Moderation, the decline in output variability in countries like the United States over the past twenty years, and this hypothesis should be a topic for future research. The bottom line, however, is that it is not at all clear whether globalization increases or reduces output volatility.

That said, as I have emphasized in my speeches and writings (Mishkin, 2006a, b; Mishkin, 2007b), I strongly believe that globalization is and has been a key factor in promoting economic growth. Globalization not only promotes a more competitive economic environment-which forces business to innovate-- but it also creates strong incentives for institutional reform to make markets work better. Globalization in recent years has not only enabled hundreds of millions of people in countries like China and India to escape abject poverty (income of less than \$1 per day) but has also helped economies like ours in the United States to be highly dynamic, which is essential to our future economic well-being. 


\section{Globalization and the Monetary Transmission Mechanism}

Four questions naturally arise when we consider whether globalization has changed the monetary transmission mechanism, that is, how monetary policy influences inflation and output: (1) Has globalization led to a decline in the sensitivity of inflation to domestic output gaps (the difference between actual and potential output) and thus to domestic monetary policy? In other words, has globalization made the Phillips curve flatter? (2) Are foreign output gaps playing a more prominent role in the domestic inflation process, so that domestic monetary policy has more difficulty stabilizing inflation? (3) Can domestic monetary policy still control domestic interest rates and so stabilize both inflation and output? (4) Are there other ways, besides possible influences on inflation and interest rates, in which globalization may have affected the transmission mechanism of monetary policy?

Has globalization led to a decline in the sensitivity of inflation to domestic output gaps (the difference between actual and potential output) and thus to domestic monetary policy?

In recent years, we have clearly witnessed a decline in the sensitivity of inflation to the domestic output gap (a flattening of the Phillips curve) in the United States and other advanced countries (Borio and Filardo, 2007; International Monetary Fund, 2006; Ihrig and others, 2007; Pain, Koske, and Sollie, 2006). Globalization might make inflation less responsive to rising domestic resource utilization because households and businesses can go outside the country to buy goods and services, so there will be less pressure for domestic prices to rise. Another way of thinking about this point is to recognize that globalization might reduce the likelihood of having supply bottlenecks as domestic resource utilization rises. Although this story is a plausible one, research at the Federal Reserve Board and elsewhere finds no evidence that the flattening of the 
Phillips curve reflects the process of increasing trade integration (Ihrig and others, 2007; Ball, 2006; Wynne and Kersting, 2007). ${ }^{1}$

Rather than globalization being an important factor leading to flatter Phillips curves, I would argue (as in Mishkin, 2007a) that flatter Phillips curves are the direct result of better monetary policy that has anchored inflation expectations. Because monetary authorities are focusing more on establishing a stronger nominal anchor, a rise in resource utilization will not lead to a rise in expected inflation. Instead, households and businesses will expect monetary authorities to take the necessary steps to ensure that the economy will not overheat, and, as a result, they will not push for higher prices and wages. Not only is this explanation for decreased sensitivity of inflation to output gaps more consistent with empirical evidence (see Mishkin, 2007a; Roberts, 2006), but it is more consistent with the timing of when Phillips curves became flatter. In the United States, Phillips curves started to flatten in the 1980s, well before the recent surge of globalization but just after inflation expectations started to become anchored.

Are foreign output gaps playing a more prominent role in the domestic inflation process, so that domestic monetary policy has more difficulty stabilizing inflation?

As economies have become more open, foreign factors may have become more important in the determination of domestic inflation. Research at the Bank for International Settlements (Borio and Filardo, 2007) seems to provide evidence that foreign resource slack has superseded domestic slack as a key determinant of domestic inflation. However, research at the Federal Reserve Board (Ihrig and others, 2007) and at the OECD (Pain, Koske, and Sollie, 2006) point out that the specification of the Phillips curve in Borio and Filardo (2007) is problematic. Their key findings are not robust to alternative specifications. Moreover, their specification leads to 
econometric difficulties because it causes serial correlation of the residuals that is not corrected for.

Using more-conventional specifications of Phillips curves, the research at the Federal Reserve Board (Ihrig and others, 2007) and the OECD (Pain, Koske, and Sollie, 2006), as well as Ball (2006), finds that foreign output gaps are not important determinants of domestic inflation. However, foreign factors could more plausibly play a role in the inflation process through import prices. As economies become more open and imports play a bigger role in the economy, consumer prices may become more sensitive to import prices. Indeed, CPI inflation does appear to have become more sensitive to import prices over time, both in the United States and in other OECD countries (Pain, Koske, and Sollie, 2006). ${ }^{2}$

Can domestic monetary policy still control domestic interest rates and so stabilize both inflation and output?

In principle, the increasing global integration of financial markets, by reducing the scope for individual central banks to control domestic interest rates, could hamper the ability of monetary policy to stabilize prices and economic activity. Indeed, some evidence appears to suggest that foreign factors influence interest rates; for example, the global saving glut does seem to have led to somewhat lower long-term interest rates by reducing term premiums (Warnock and Warnock, 2006). More generally, research points to important linkages between U.S. and foreign interest rates and other asset prices (Ehrmann, Fratzscher and Rigobon, 2005; Faust and others, 2007). However, central banks still retain the ability to control short-term interest rates, which affect the domestic cost of credit and long-term interest rates, and so can continue to do their job of stabilizing inflation and output. 
Are there other ways, besides possible influences on inflation and interest rates, in which globalization may have affected the transmission mechanism of monetary policy?

The preceding discussion might lead to the conclusion that globalization has not had important effects, either on the behavior of inflation or the ability of monetary policy to affect the economy. However, globalization might have an effect on the process of monetary transmission that does not operate through Phillips-curve-type mechanisms.

One of the key transmission channels of monetary policy is the exchange rate. A tightening of monetary policy, for example, raises U.S. interest rates relative to those abroad, thereby inducing upward pressure on the foreign exchange value of the dollar. An appreciation of the dollar, in turn, restrains exports (because the price of U.S. goods rises when measured in foreign currencies) and stimulates imports (because imports become cheaper in dollar terms). The resulting decrease in net exports implies a reduction in aggregate demand. In addition, an appreciation of the dollar that leads to a decline in import prices also helps restrain overall U.S. inflation.

By expanding the share of tradable goods and services in the economy, globalization might increase the role of the exchange rate as a transmission channel of monetary policy and could reduce the role of the interest rate channel. The larger the share of imports and exports in the economy, the greater the change in net exports--and, hence, in the contribution of net exports to gross domestic product (GDP) growth--for a given change in the exchange rate. In addition, the larger the share of imports in the economy, the larger should be the effect on overall CPI inflation of a given change in import prices when the exchange rate changes. ${ }^{3}$ (This effect is explicitly incorporated in Federal Reserve staff models of U.S. inflation, which weight import prices by the share of imports in the consumption basket.) 
By the same token, the effect of the interest rate channel on overall economic activity may be diminished by greater trade integration as changes in domestic demand are offset by induced changes in imports. Guerrieri, Gust, and López-Salido (2007), for example, find that shocks to domestic demand move output less in more-open economies because they lead to larger offsetting movements in the trade balance. Supporting this result, Ihrig and others (2007) conclude that correlations between real GDP growth and real domestic demand growth have declined in recent decades in the United States and several other industrial economies.

In addition to increasing the sensitivity of the economy to changes in exchange rates, globalization may have increased the sensitivity of exchange rates to monetary policy. Over the past few decades, as capital controls have been eliminated in most major economies and the levels of home bias in portfolio investment have declined, financial markets around the world have become more tightly integrated. An implication of this financial globalization is that demand for domestic and foreign assets is likely to have become more sensitive to international differences in perceived rates of return. Accordingly, monetary policy actions may now exert more influence on exchange rates than was the case when markets were less tightly integrated and assets of different countries were perceived to be less substitutable for each other. This linkage between globalization and the effect of monetary policy on exchange rates is somewhat speculative but represents a worthwhile avenue for further research.

\section{Why Has Inflation Declined in Recent Years?}

What does all the preceding analysis tell us about why we have had better inflation performance in recent years? I don't know of anyone who would have predicted twenty years ago that inflation would be so low and stable in so many countries. Has globalization been an 
important part of the story of inflation's remarkable decline in recent years? In terms of direct effects, the discussion here provides a clear-cut answer: No. Inflation has come down in the old-fashioned way. Tighter monetary policy and a commitment to price stability by central banks throughout the world have led to lower inflation and an anchoring of inflation expectations. These policies have had huge benefits--not only the achievement of low and stable inflation but also an improvement in the overall performance of the economy.

Globalization, however, may have helped reduce inflation in more-subtle ways. By fostering increased interactions among central banks, academics, and the public in many different countries, globalization has helped spread a common culture that stresses the benefits of achieving price stability. The resulting increased focus on price stability has been a key reason for the reduction of inflation worldwide.

\section{Conclusion}

The increasing integration of global product, labor, and financial markets has the potential to significantly alter the behavior of the economy, a development that could complicate the task of monetary policy. In practice, however, the behavior of the U.S. and global economies does not appear to have radically changed in recent years. The Federal Reserve and other central banks retain the ability to stabilize prices and output. 


\section{References}

Ball, Laurence M. (2006). “Has Globalization Changed Inflation?” NBER Working Paper Series 12687. Cambridge, Mass.: National Bureau of Economic Research, November, www.nber.org/papers.

Barro, Robert J., and David B. Gordon (1983). "Rules, Discretion, and Reputation in a Model of Monetary Policy,” Journal of Monetary Economics, vol. 12 (no. 1), pp. 101-22.

Bergin, Paul R., Robert C. Feenstra, and Gordon Hanson (2007). “Outsourcing and Volatility,” paper presented at the Conference on Globalization and the Macroeconomy, European Central Bank, July 23-24, www.ecb.int/events/conferences/html/global_macro.en.html.

Borio, Claudio E.V., and Andrew Filardo (2007). "Globalisation and Inflation: New CrossCountry Evidence on the Global Determinants of Domestic Inflation,” BIS Working Paper 227. Basel: Bank for International Settlements, May, www.bis.org/forum/research.htm.

Chen, Natalie, Jean Imbs, and Andrew Scott (2007). "The Dynamics of Trade and Competition,” paper presented at the Conference on Globalization and the Macroeconomy, European Central Bank, July 23-24, www.ecb.int/events/conferences/html/global_macro.en.html.

Ehrmann, Michael, Marcel Fratzscher, and Roberto Rigobon (2005). "Stocks, Bonds, Money Markets, and Exchange Rates: Measuring International Financial Transmission,” ECB Working Paper No. 452. Frankfurt: European Central Bank, March, www.ecb.int/pub/scientific/wps/date/html/wps2005.en.html.

Erceg, Christopher, Christopher Gust, and David López-Salido (2007). “The Transmission of Domestic Shocks in Open Economies," paper presented at “International Dimensions of Monetary Policy," a conference sponsored by the National Bureau of Economic Research Conference on Policy, held in Barcelona, June 11-13, www.nber.org/booksnew/gert07-1.

Faust, Jon, John H. Rogers, Shing-Yi B. Wang, and Jonathan H. Wright (2007). “The HighFrequency Response of Exchange Rates and Interest Rates to Macroeconomic Announcements," Journal of Monetary Economics, vol. 54 (May), pp. 1051-68.

Friedman, Milton (1974). “Perspectives on Inflation,” Newsweek, June 24.

Guerrieri, Luca, Christopher Gust, and David López-Salido (2007). "International Competition and Inflation: A New Keynesian Perspective,” unpublished paper, Board of Governors of the Federal Reserve System, August.

Ihrig, Jane, Steven B. Kamin, Deborah Lindner, and Jaime Marquez (2007). “Some Simple Tests of the Globalization and Inflation Hypothesis," International Finance Discussion Papers 891. Washington: Board of Governors of the Federal Reserve System, April, www.federalreserve.gov/pubs/ifdp. 
International Monetary Fund (2006). "How Has Globalization Affected Inflation?” in Globalization and Inflation, IMF World Economic Outlook. Washington: International Monetary Fund, pp. 97-134, www.imf.org/pubs/ft/weo/2006/01.

Kamin, Steven B., Mario Marazzi, and John W. Schindler (2006). “The Impact of Chinese Exports on Global Import Prices," Review of International Economics, vol. 14 (May), pp. 179201.

Markusen, James R. (2007). “Trade and Foreign Direct Investment in Business Services: A Modelling Approach," paper presented at the Conference on Globalization and the Macroeconomy, European Central Bank, July 23-24, www.ecb.int/events/conferences/html/global_macro.en.html.

Mishkin, Frederic S. (2006a). The Next Great Globalization: How Disadvantaged Nations Can Harness Their Financial Systems to Get Rich, Princeton: Princeton University Press.

---------- (2006b). “Globalization: A Force for Good?” speech delivered at Baruch College, New York, N.Y., October 12, www.federalreserve.gov/newsevents.

317-334 (2007a). “Inflation Dynamics,” International Finance Vol. 10, No. 3(2007), pp. ---------- (2007b). “Globalization and Financial Development,” speech delivered to the New Perspectives on Financial Development Conference, Washington, D.C., April 26, www.federalreserve.gov/newsevents.

Pain, Nigel, Isabell Koske, and Marte Sollie (2006). "Globalisation and Inflation in the OECD Economies,” OECD Economics Department Working Paper No. 524. Paris: Organisation for Economic Co-operation and Development, November, www.oecd.org/findDocument.

Roberts, John M. (2006). “Monetary Policy and Inflation Dynamics,” International Journal of Central Banking, vol. 2 (September), pp. 193-230.

Rogoff, Kenneth S. (2003). "Globalization and Global Disinflation,” paper presented at "Monetary Policy and Uncertainty: Adapting to a Changing Economy," a symposium sponsored by the Federal Reserve Bank of Kansas City, held in Jackson Hole, Wyo., August 28-30, www.kansascityfed.org/publicat/sympos/2003/pdf/Rogoff2003.pdf.

Warnock, Francis E., and Veronica Cacdac Warnock (2006). "International Capital Flows and U.S. Interest Rates,” NBER Working Paper Series 12560. Cambridge, Mass.: National Bureau of Economic Research, October, www.nber.org/papers.

Wynne, Mark A., and Erasmus K. Kersting (2007). “Openness and Inflation,” Federal Reserve Bank of Dallas, Staff Papers, vol. 2007 (April), pp. 1-28, http://dallasfed.org/research/staff. 
${ }^{1}$ International Monetary Fund (2006) does find some evidence supporting the hypothesis that globalization flattens the Phillips curve: In a cross-country regression of inflation on, among other factors, the trade share multiplied by the output gap, the interaction term is found to have a significant negative coefficient. In the simpler specification of Ihrig and others (2007), however, the effect of this interaction term is not significant.

${ }^{2}$ International Monetary Fund (2006) finds indirect evidence supporting this channel--namely, that inflation is affected by relative import prices multiplied by import shares in GDP and that import shares have been rising over time. Ihrig and others (2007) document a rise in the sensitivity of U.S. inflation to import prices over time, although they do not identify such a trend in other countries.

${ }^{3}$ A qualification of this point is that even as the share of imports in U.S. spending has risen, the pass-through of exchange rates into import prices has declined. However, we do not know whether the decline in pass-through is merely transitory or will be sustained. 